\title{
Piperlongumine induces apoptosis and autophagy in leukemic cells through targeting the PI3K/Akt/mTOR and p38 signaling pathways
}

\author{
HONGFEI WANG, YONGQIANG WANG, HONGMEI GAO, BING WANG, LIN DOU and YIN LI \\ Department of Intensive Care Unit, Tianjin First Center Hospital, Nankai, Tianjin 300192, P.R. China
}

Received November 14, 2015; Accepted June 16, 2017

DOI: $10.3892 / \mathrm{ol} .2017 .7498$

\begin{abstract}
Piperlongumine is an alkaloid compound extracted from Piper longum L. It is a chemical substance with various pharmacological effects and medicinal value, including anti-tumor, lipid metabolism regulatory, antiplatelet aggregation and analgesic properties. The present study aimed to understand whether piperlongumine induces the apoptosis and autophagy of leukemic cells, and to identify the mechanism involved. Cell viability and autophagy were detected using MTT, phenazine methyl sulfate and trypan blue exclusion assays. The apoptosis rate was calculated using flow cytometry. The protein expression levels of microtubule-associated protein 1A/1B-light chain 3, Akt and mechanistic target of rapamycin (mTOR) were measured using western blotting. The cell growth of leukemic cells was completely inhibited following treatment with piperlongumine, and marked apoptosis was also induced. Dead cells as a result of autophagy were stained using immunofluorescence and observed under a light microscope. Phosphoinositide 3-kinase (PI3K)/Akt/mTOR signaling was suppressed by treatment with piperlongumine, while p38 signaling and caspase- 3 activity were induced by treatment with piperlongumine. It was concluded that piperlongumine induces apoptosis and autophagy in leukemic cells through targeting the PI3K/Akt/mTOR and p38 signaling pathways.
\end{abstract}

\section{Introduction}

Leukemia is a kind of malignant tumor of the hemopoietic system posing a great threat to human health (1). The mortality rate ranks sixth in males and eighth in females among all malignant tumors in China in all age groups, and first among children

Correspondence to: Dr Yin Li, Department of Intensive Care Unit, Tianjin First Center Hospital, 24 Fukang Road, Nankai, Tianjin 300192, P.R. China

E-mail: yinlilitj@163.com

Key words: piperlongumine, leukemic cells, PI3K/Akt/mTOR, autophagy, p38 and adults under 35 years of age (2). There is a higher number of patients with acute myeloid leukemia (AML) than with acute lymphoblastic leukemia (ALL) (AML:ALL=2.67:1.00); AML is mostly reported in young adults $(76.2 \%)$ and has a negative effect on health (3). In contrast to solid tumors, leukemia is a kind of 'liquid tumor' that cannot be removed by surgery (4). At present, chemotherapy is still the most widely used method in the treatment of patients with leukemia due to the difficulty in matching bone marrow for transplantation and the high price of molecular targeted therapy (5). However, the current research focus is to identify novel chemotherapy drugs with strong activity and low toxicity from natural drugs that are able to overcome chemotherapeutic resistance and adverse side reactions (6).

Following cell apoptosis, autophagy has become the hot research topic as type-II programmed death in recent years (5). Autophagy involves the formation of autophagic vacuoles, their integration with lysosomes and the degradation of the contents of these autophagosomes (7). In contrast to cell apoptosis, autophagy has a dual regulatory function in cell survival, which serves an important role in the occurrence and development of tumors (8). Previous studies have shown that intracellular autophagy in certain tumor cells can kill these cells and maintain the normal internal body environment in the early stages of cancer $(9,10)$. However, upon the formation of tumors, autophagy promotes apoptosis by removing damaged organelles, so as to reduce the growth of tumor cells $(11,12)$. Therefore, researching the mechanism of autophagy development has a good prospect in clinical application for the prevention and treatment of cancer (13).

Piperlongumine (Fig. 1) belongs to the family of alkaloids, and exhibits a variety of pharmacological effects and pharmacological activities, including antiplatelet aggregation, analgesia and antifungal properties (14). In addition, piperlongumine has a marked cytotoxic effect on tumor cells and can regulate blood lipid metabolism in hyperlipidemic rats (14). Previous studies have shown that piperlongumine has a specific cytotoxic effect on a variety of tumor cells, but exhibits low toxicity towards normal cells $(14,15)$. Therefore, piperlongumine is an extract of a herb used in traditional Chinese medicine, which has the potential to selectively kill tumors (14). The pharmacological effects of piperlongumine mainly include antitumor, antiplatelet aggregation, analgesic, antifungal, anti-schistosomiasis, anti-anxiety and 
anti-depression effects (16). The aim of the present study was to investigate whether piperlongumine induces apoptosis and autophagy in leukemic cells, and to explore the underlying molecular mechanisms.

\section{Materials and methods}

Cell lines and mice. Leukemic monocytic lymphoma U937 cells were purchased from the Cell Bank of Type Culture Collection of the Chinese Academy of Sciences (Shanghai, China) and cultured in RPMI-1640 medium (pH 6.8) supplemented with $10 \%$ fetal bovine serum (both from Invitrogen; Thermo Fisher Scientific, Inc., Waltham, MA, USA) and antibiotics (50 IU/ml penicillin $\mathrm{G}$ and $50 \mu \mathrm{g} / \mathrm{ml}$ streptomycin), and were incubated at $37^{\circ} \mathrm{C}$ in a humidified atmosphere containing $5 \% \mathrm{CO}_{2}$.

Cell viability assay and immunofluorescence. The effect of piperlongumine on the viability of U937 cells was evaluated. U937 cells $\left(2.5-5.0 \times 10^{4}\right.$ cells $/ 200 \mu 1$ of RPMI-1640 medium/well) were seeded in 96-well tissue culture plates and incubated with piperlongumine $(0-20 \mu \mathrm{M})$ for $48 \mathrm{~h}$ at $37^{\circ} \mathrm{C}$ in the presence of $5 \% \mathrm{CO}_{2}$. MTT $(2.0 \mathrm{mg} / \mathrm{ml})$ and phenazine methyl sulfate $(0.92 \mathrm{mg} / \mathrm{ml})$ were added into every well and incubated at $37^{\circ} \mathrm{C}$ for $3 \mathrm{~h}$. The absorbance was measured at $490 \mathrm{~nm}$ in an ELISA reader (Bio-Rad Laboratories, Inc., Hercules, CA, USA). Cells (at 60-70\% confluence) were seeded in 6-well tissue culture plates and treated with piperlongumine $(0-20 \mu \mathrm{M})$ for $48 \mathrm{~h}$ at $37^{\circ} \mathrm{C}$ in the presence of $5 \%$ $\mathrm{CO}_{2}$.

U937 cells treated with piperlongumine $(0,5,10$ and $20 \mu \mathrm{M})$ were washed with PBS and fixed using 4\% paraformaldehyde for $15 \mathrm{~min}$ at room temperature. Cells were incubated with Triton X-100 (0.1\%) for $10 \mathrm{~min}$ at room temperature and then incubated with anti-LC3 antibodies (cat. no. 3868; 1:3,000; Cell Signaling Technology, Inc., Beverly, MA, USA) at $4^{\circ} \mathrm{C}$ overnight. Cells were incubated with Alexa Fluor 488-labeled goat anti-rabbit secondary antibody (Thermo Fisher Scientific, Inc.) for $1 \mathrm{~h}$ at room temperature in darkness. Cells were observed using a Nikon Eclipse E800 fluorescence microscope and NIS-Elements 4.0 software (all from Nikon; Tokyo, Japan).

Apoptosis assay. U937 cells $\left(2.5 \times 10^{5}\right.$ cells $\left./ \mathrm{ml}\right)$ were incubated with piperlongumine $(0-20 \mu \mathrm{M})$ for $48 \mathrm{~h}$ at $37^{\circ} \mathrm{C}$ in the presence of $5 \% \mathrm{CO}_{2}$. Cells were washed twice with PBS and resuspended in $100 \mu \mathrm{l}$ of Annexin V binding buffer (pH 7.4) (BD Biosciences, Franklin Lakes, NJ, USA). Then, annexin V-fluorescein isothiocyanate (BD Biosciences) was added and incubated for 15 min under dark conditions. Propidium iodide $(0.1 \mu \mathrm{g} / \mathrm{ml}$; Sigma-Aldrich; Merck KGaA, Darmstadt, Germany) was added just prior to signal acquisition. The apoptosis rate was acquired using a FACSAria flow cytometer (BD Biosciences) and analyzed with FACSDiva 7.6.1 software (BD Biosciences).

Western blotting. Total cellular proteins were isolated from U937 cells $\left(2.5 \times 10^{5}\right.$ cells $\left./ \mathrm{ml}\right)$ incubated with piperlongumine $(0-20 \mu \mathrm{M})$ for $48 \mathrm{~h}$ at $37^{\circ} \mathrm{C}$ in the presence of $5 \% \mathrm{CO}_{2}$. Cells were lysed using radioimmunoprecipitation assay (RIPA)

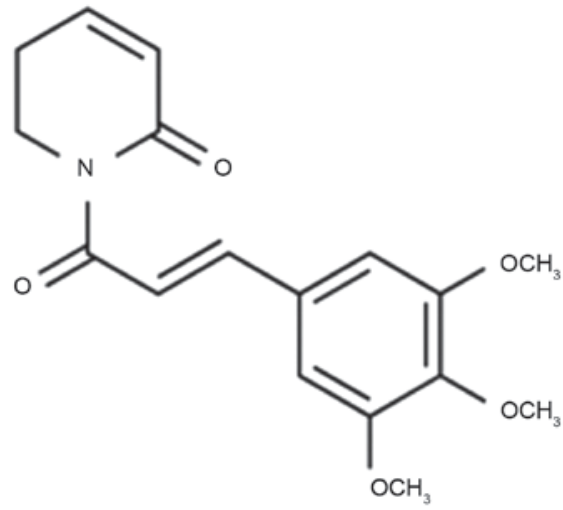

Figure 1. Chemical structure of piperlongumine.

buffer (Beyotime Institute of Biotechnology, Jiangsu, China) and centrifuged for $10 \mathrm{~min}$ at $4^{\circ} \mathrm{C}$ at $10,000 \mathrm{x}$ g. Protein concentration was estimated using the bicinchoninic acid method (Beyotime Institute of Biotechnology). Electrophoretic separations were carried out on $10 \%$ SDS-PAGE, and the proteins were then electrotransferred onto a polyvinylidene fluoride membrane. Blots were blocked for $1 \mathrm{~h}$ at $37^{\circ} \mathrm{C}$ in TBS containing $0.01 \%$ Tween-20 (TBST) and 5\% skimmed milk, and probed overnight at $4^{\circ} \mathrm{C}$ with appropriate primary antibodies: Anti-microtubule-associated protein 1A/1B-light chain 3 (LC3-I; cat. no. 3868; 1:3,000), anti-phosphorylated (p)-Akt (cat. no. 4228; 1:3,000), anti-Akt (cat. no. 6211; 1:3,000), anti-p-mechanistic target of rapamycin (mTOR; cat. no. 2974; 1:3,000), anti-p-p38 (cat. no. 4511, 1:2,000) and anti- $\beta$-actin (cat. no. 4970, 1:2,000) (all from Cell Signaling Technology, Inc., Beverly, MA, USA) antibodies. Next, the membranes were washed with TBST and incubated with anti-rabbit IgG, HRP-linked antibody (cat. no. 7074, 1:5,000, Cell Signaling Technology, Inc.) at $37^{\circ} \mathrm{C}$ for $1 \mathrm{~h}$. Proteins were visualized using BeyoECL Plus (Beyotime Institute of Biotechnology) and analyzed uisng Bio-Rad Laboratories Quantity One software 3.0 (Bio-Rad Laboratories, Inc., Hercules, CA, USA).

Measurement of caspase activity. U937 cells $\left(2.5-5.0 \times 10^{4}\right.$ cells/ $200 \mu 1$ of RPMI-1640 medium/well) were seeded in 96-well tissue culture plates and incubated with piperlongumine $(0-20 \mu \mathrm{M})$ for $48 \mathrm{~h}$ at $37^{\circ} \mathrm{C}$ in the presence of $5 \% \mathrm{CO}_{2}$. Cells were lysed using RIPA buffer (Beyotime Institute of Biotechnology) and centrifuged for $10 \mathrm{~min}$ at $4^{\circ} \mathrm{C}$ at $10,000 \mathrm{x} \mathrm{g}$. Protein concentration was estimated using the BCA Protein Assay kit (Beyotime Institute of Biotechnology). U937 cell lysates $(5 \mu \mathrm{g})$ were incubated in $50 \mu \mathrm{l}$ of reaction buffer and acetyl-Asp-Glu-Val-Asp p-nitroanilide (p-NA) (Beyotime Institute of Biotechnology) at $37^{\circ} \mathrm{C}$ for $5 \mathrm{~h}$ for determination of caspase- 3 activity. The emission of pNA was measured at $405 \mathrm{~nm}$ in an ELISA reader (Bio-Rad Laboratories, Inc.).

Statistical analysis. All experiments were repeated independently at least three times using SPSS 17.0 (SPSS, Inc., Chicago, IL, USA). The values were expressed as mean \pm standard error of the mean, and statistical analyses were performed with a two-way analysis of variance followed by the Student-Newman-Keuls test. 
A

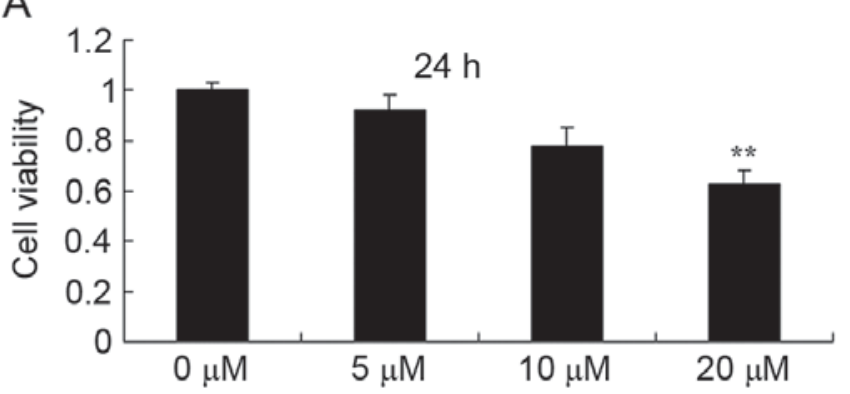

B

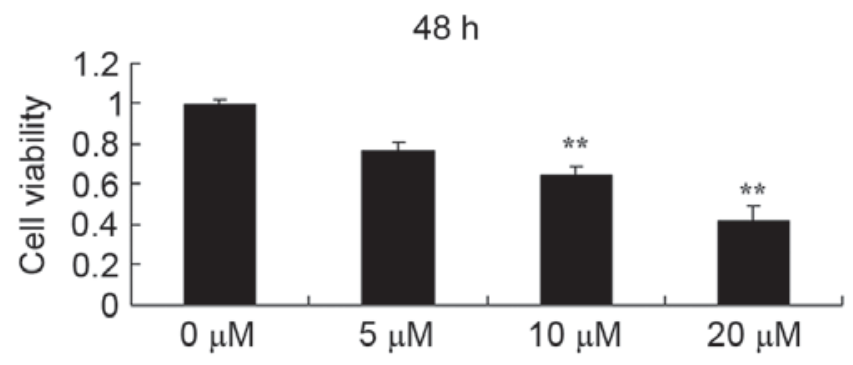

Figure 2. Piperlongumine suppresses the proliferation of leukemic cells at (A) 24 and (B) $48 \mathrm{~h} .{ }^{* *} \mathrm{P}<0.01$ vs. U937 cells incubated with $0 \mu \mathrm{M}$ of piperlongumine.

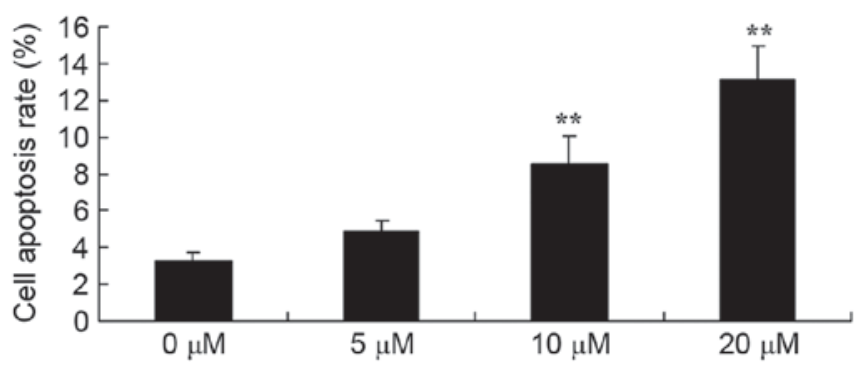

Figure 3. Piperlongumine induces the apoptosis of leukemic cells. ${ }^{* *} \mathrm{P}<0.01$ vs. U937 cells incubated with $0 \mu \mathrm{M}$ of piperlongumine.

\section{Results}

Piperlongumine suppresses cell proliferation in leukemic cells. The anticancer effect of piperlongumine in terms of suppressing the proliferation of leukemic cells was evaluated. An MTT assay was used to analyze the change in cell proliferation in U937 cells. As shown in Fig. 2, 0-20 $\mu \mathrm{M}$ of piperlongumine could suppress the proliferation of U937 cells in a time- and dose-dependent manner. At $20 \mu \mathrm{M}$, piperlongumine significantly suppressed the proliferation of U937 cells at $24 \mathrm{~h}$, while 10 or $20 \mu \mathrm{M}$ of piperlongumine significantly suppressed the proliferation of U937 cells at 48 h (Fig. 2).

Piperlongumine induces apoptosis in leukemic cells. To further confirm the role of apoptosis in the effect of piperlongumine on leukemic cells, the apoptosis rate was evaluated using flow cytometry. The results revealed that $0-20 \mu \mathrm{M}$ of piperlongumine induced the apoptosis of U937 cells in a dose-dependent manner (Fig. 3). Treatment with 10 or $20 \mu \mathrm{M}$ of piperlongumine significantly induced the apoptosis of U937

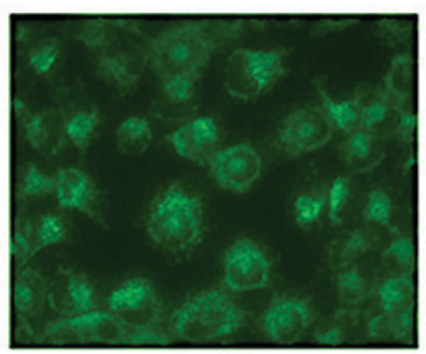

$0 \mu \mathrm{M}$

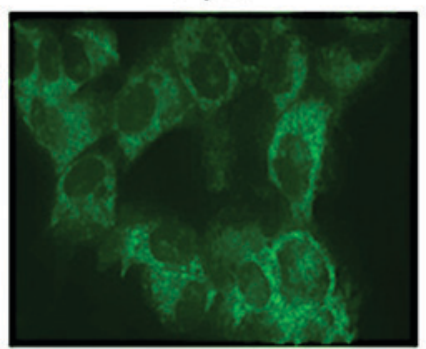

$5 \mu \mathrm{M}$

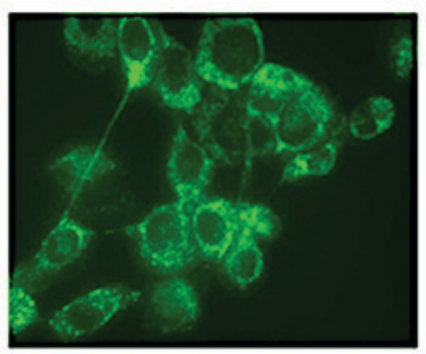

$10 \mu \mathrm{M}$

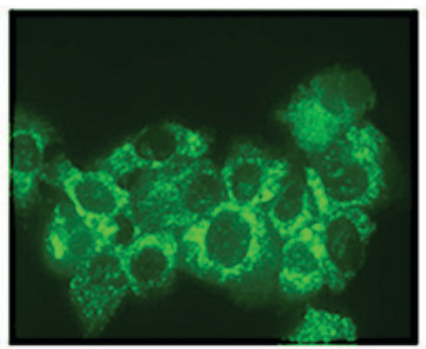

$20 \mu \mathrm{M}$

Figure 4. Piperlongumine induces the autophagy of leukemic cells. Measured via immunofluorescence targeted at microtubule-associated protein 1A/1B-light chain 3 .

cells, compared with that of U937 cells incubated with $0 \mu \mathrm{M}$ of piperlongumine (Fig. 3).

Piperlongumine induces autophagy in leukemic cells. The autophagy of U937 cells was measured by fluorescence microscopy targeted at LC3. An increase in the autophagy of U937 cells incubated with $0-20 \mu \mathrm{M}$ of piperlongumine was observed (Fig. 4). Treatment with 10 or $20 \mu \mathrm{M}$ of piperlongumine activated the autophagy of U937 cells, compared with that of U937 cells incubated with $0 \mu \mathrm{M}$ of piperlongumine (Fig. 4).

Piperlongumine induces LC3-I expression in leukemic cells. Upon co-incubation of U937 cells with $0-20 \mu \mathrm{M}$ of piperlongumine for $48 \mathrm{~h}$, the protein expression of LC3-I was explored using western blotting. The protein expression of LC3-I was induced by $0-20 \mu \mathrm{M}$ of piperlongumine in a dose-dependent 
A

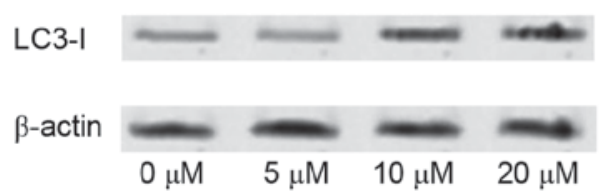

B

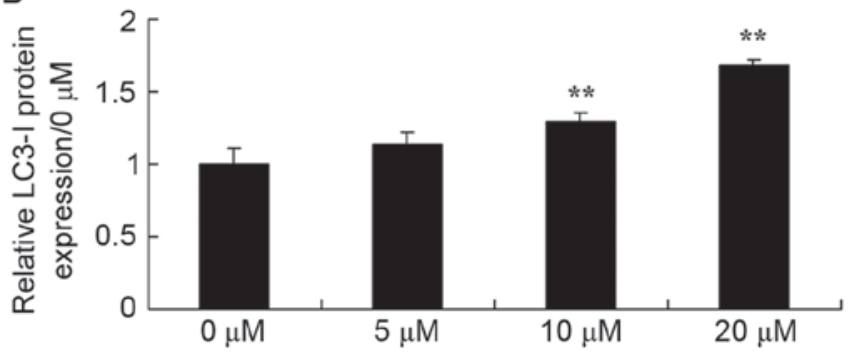

Figure 5. Piperlongumine induces LC3-I expression in leukemic cells. (A) Western blot analysis of LC3-I protein expression induced by piperlongumine. (B) Statistical analysis of LC3-I protein expression in leukemic cells. ${ }^{* *} \mathrm{P}<0.01$ vs. U937 cells incubated with $0 \mu \mathrm{M}$ of piperlongumine. LC3-I, microtubule-associated protein 1A/1B-light chain 3 .

A

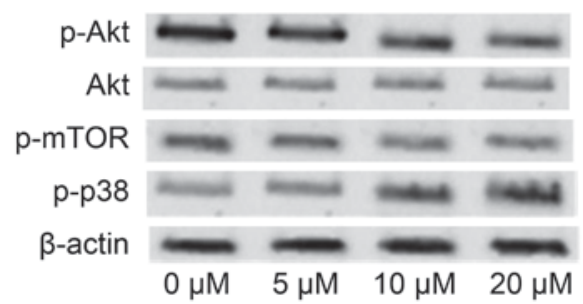

C

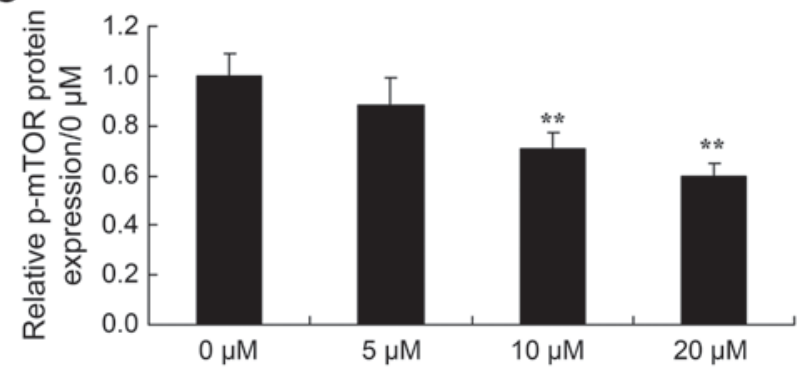

B
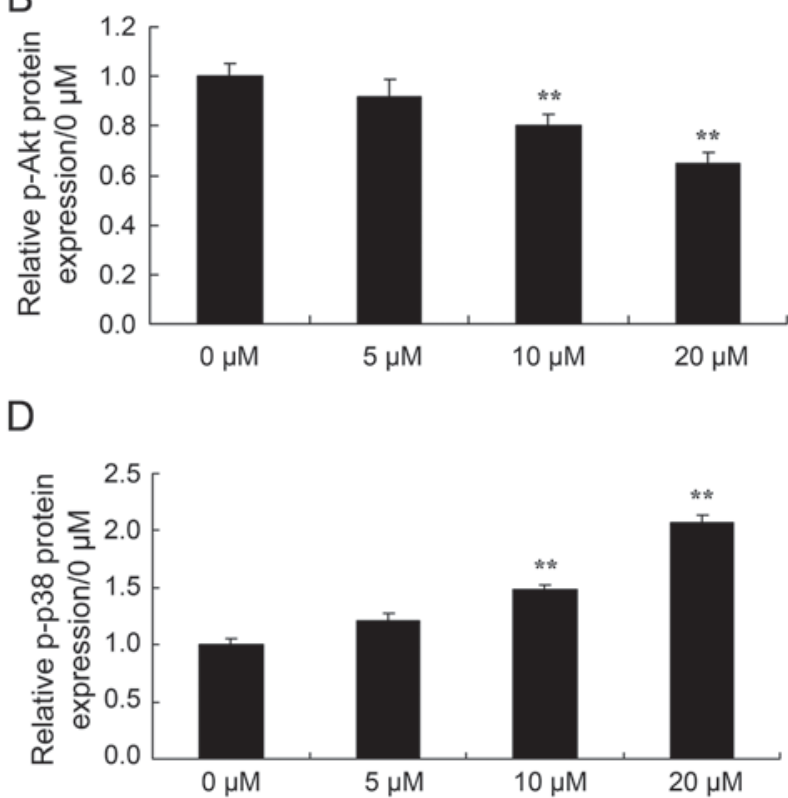

Figure 6. Piperlongumine reduces p-Akt and p-mTOR, and induces p-p38 protein expression in leukemic cells. (A) Piperlongumine affects p-Akt, Akt, p-mTOR and p-p38 protein expression, according to western blot analysis. Statistical analysis of (B) p-Akt/Akt, (C) p-mTOR and (D) p-p38 protein expression levels in leukemic cells. ${ }^{* *} \mathrm{P}<0.01$ vs. U937 cells incubated with $0 \mu \mathrm{M}$ of piperlongumine. p, phosphorylation; mTOR, mechanistic target of rapamycin.

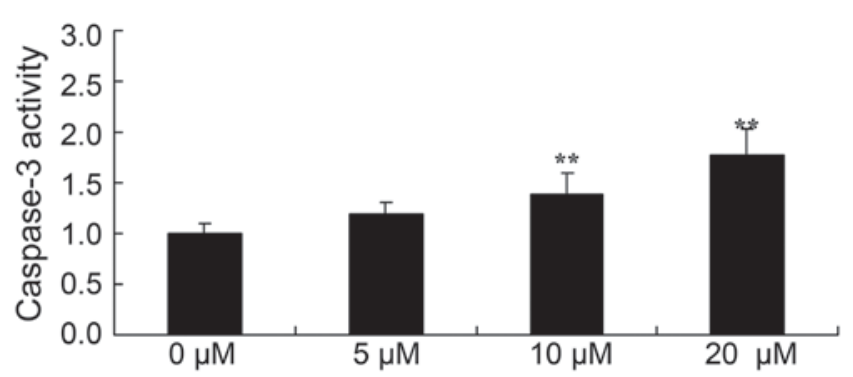

Figure 7. Piperlongumine induces caspase- 3 activity in leukemic cells. ${ }^{* *} \mathrm{P}<0.01$ vs. U937 cells incubated with $0 \mu \mathrm{M}$ of piperlongumine.

manner (Fig. 5). In particular, 10 or $20 \mu \mathrm{M}$ of piperlongumine significantly increased LC3-I protein expression in U937 cells, compared with that of U937 cells incubated with $0 \mu \mathrm{M}$ of piperlongumine (Fig. 5).

Piperlongumine reduces Akt levels in leukemic cells. To analyze the mechanism of piperlongumine on autophagy, the phosphorylation of Akt in U937 cells was determined by western blotting. As shown in Fig. 6, a dose-dependent decrease in the ratio of p-Akt/Akt protein expression was detected in U937 cells following treatment with $0-20 \mu \mathrm{M}$ of piperlongumine. Particularly, 10 or $20 \mu \mathrm{M}$ of piperlongumine significantly reduced the p-Akt/Akt ratio in U937 cells, compared with that of U937 cells incubated with $0 \mu \mathrm{M}$ of piperlongumine (Fig. 6A and B).

Piperlongumine reduces mTOR levels in leukemic cells. To further analyze the mechanism of piperlongumine on autophagy, the protein expression of p-mTOR was measured. Fig. 6 shows that $0-20 \mu \mathrm{M}$ of piperlongumine inhibited p-mTOR protein expression in U937 cells in a dose-dependent manner. Treatment with 10 or $20 \mu \mathrm{M}$ of piperlongumine significantly inhibited p-mTOR protein expression in U937 cells, compared with that of the $0 \mu \mathrm{M}$ of piperlongumine group (Fig. 6A and C).

Piperlongumine induces the phosphorylation of p38 protein in leukemic cells. To investigate the protein expression of $\mathrm{p} 38$, 
U937 cells were incubated with piperlongumine $(0-20 \mu \mathrm{M})$ for $48 \mathrm{~h}$. Treatment with $0-20 \mu \mathrm{M}$ of piperlongumine induced the protein expression of p-p38 in U937 cells (Fig. 6A and D). Treatment with 10 or $20 \mu \mathrm{M}$ of piperlongumine significantly induced p-p38 protein expression in U937 cells, compared with that of $\mathrm{U} 937$ cells incubated with $0 \mu \mathrm{M}$ of piperlongumine (Fig. 6A and D).

Piperlongumine induces caspase-3 activity in leukemic cells. In order to assess the role of caspase-3 activity in U937 cells, the cells were co-incubated with $0-20 \mu \mathrm{M}$ of piperlongumine for $48 \mathrm{~h}$. As shown in Fig. 7, 0-20 $\mu \mathrm{M}$ of piperlongumine increased the caspase-3 activity of U937 cells in a dose-dependent manner. Particularly, treatment with 10 or $20 \mu \mathrm{M}$ of piperlongumine significantly increased the caspase- 3 activity of U937 cells, compared with that of U937 cells incubated with $0 \mu \mathrm{M}$ of piperlongumine (Fig. 7).

\section{Discussion}

Leukemia is a type of malignant tumor of the hemopoietic system posing a severe threat to human health, and its mortality rate ranks first among all malignant tumors among children and adults under 35 years of age (17). Its morbidity and mortality are increasing, and it is urgently required to identify novel therapeutics against leukemic cells (18). Dhillon et al reported that piperlongumine induces pancreatic cancer cell death (19). The present data clearly demonstrated that piperlongumine significantly suppresses cell proliferation and induces apoptosis in U937 cells.

Autophagy is a conserved self-degradation system in eukaryotic cells, which is involved in numerous physiological and pathological processes (13). The autophagosome is the typical characteristic of autophagy, and the regulation of the formation and degradation of the autophagosome is the main regulation of autophagy (8). Due to the dual characteristics of autophagy in promoting both cell growth and death, autophagy determines cell survival to certain extent (20). Autophagy is closely associated with tumors, and is involved in tumor development, metastasis and drug resistance (12). Targeted autophagy may become a new strategy for the treatment of cancer and drug resistance (21). Further study of autophagy in leukemic cells will clarify the mechanism of induction and regulation of autophagy in leukemic cells, and may provide a new treatment target and strategy for leukemic cells (22). In the present study, it was demonstrated that piperlongumine induces autophagy and induces expression of LC3-I protein in leukemic cells. Makhov et al demonstrated that piperlongumine promotes autophagy in a xenograft mouse model through inhibition of Akt/mTOR signaling, and mediates cancer cell death (23). Wang et al (24) showed that Piperlongumine induces autophagy of cancer cell by targeting p38 signaling.

The main function of mTOR is to inhibit the occurrence of self-autophagy via two mechanisms: i) mTOR regulates the transcription and translation of autophagy-associated genes through the activation of downstream effectors, which affects the signal transduction pathway; and ii) inhibition of mTOR can induce the occurrence of autophagy (25). PI3K/Akt is the upstream signaling pathway that activates mTOR (26). PI3K is important in cancer development, while the serine-threonine protein kinase Akt is the downstream effector of PI3K and is involved in the regulation of various biological processes, including cell metastasis, growth, development, apoptosis, and regulation of gene transcription, protein synthesis and nutritional metabolism (27). Akt may be key to the inhibition and survival signal pathway and inhibit autophagy by phosphorylating mTOR and contacting PI3K/Akt (27). The activated mTOR signal transduction pathway can inhibit the apoptosis and autophagy induced by various factors, which leads to cell cycle progression, cell growth and proliferation. It is also associated with angiogenesis, thus serving an important role in the formation, invasion and metastasis of tumors $(28,29)$. Numerous tumors exhibit mutated genes coding for proteins involved in mTOR signaling, and the resulting over-activated mTOR signaling pathway is mainly caused by abnormal expression of these proteins $(28,29)$. Previous studies have demonstrated that breast cancer, leukemia, small cell lung cancer, urinary system tumors and other diseases progress through PI3K/Akt/mTOR signaling $(22,27)$. The present study has demonstrated that piperlongumine significantly reduces $\mathrm{Akt} / \mathrm{mTOR}$ signaling in U937 cells. Wang et al previously demonstrated that piperlongumine induces apoptosis and autophagy through inhibition of the PI3K/Akt/mTOR signaling pathway in human lung cancer cells (16).

The $\mathrm{p} 38 /$ mitogen-activated protein kinase (MAPK) signaling pathway is involved in the activation of autophagy in macrophages (30). MAPK p38 mainly inhibits autophagy, and the effect of the p38/MAPK signaling pathway is markedly complex in the development of cells (31). The activation of this pathway leads to the inhibition of cell proliferation. p38 can also induce the arrest of the cell cycle into the stationary phase and promote DNA repair against the DNA damage induced by chemotherapy (32). In particular, p38 has been reported to exhibit anti-apoptotic properties in various cell lines, and may have a direct effect on tumor infiltration and metastasis (33). The present study noticed that piperlongumine significantly induced p-p38 protein expression and increased caspase-3 activity in U937 cells. Xiong et al reported that piperlongumine induces the autophagic death of primary myeloid leukemia cells through the p38/c-Jun N-terminal kinase signaling pathway (34).

In summary, the present study has demonstrated that piperlongumine significantly suppresses cell proliferation and induces apoptosis in U937 cells. Preferentially, piperlongumine significantly induced the autophagy of U937 cells through targeting the PI3K/Akt/mTOR and p38 signaling pathways. The present data suggest that piperlongumine could be applied in the treatment of leukemic cells.

\section{References}

1. Hefazi M, Siddiqui M, Patnaik M, Wolanskyj A, Alkhateeb H, Zblewski D, Elliott M, Hogan W, Litzow M and Al-Kali A: Prognostic impact of combined NPM1+/FLT3-genotype in patients with acute myeloid leukemia with intermediate risk cytogenetics stratified by age and treatment modalities. Leuk Res: Sep 3, 2015 (Epub ahead of print).

2. Ong E, Szedlak A, Kang Y, Smith P, Smith N, McBride M, Finlay D, Vuori K, Mason J, Ball ED, et al: A scalable method for molecular network reconstruction identifies properties of targets and mutations in acute myeloid leukemia. J Comput Biol 22: 266-288, 2015. 
3. Urtishak KA, Edwards AY, Wang LS, Hudome A, Robinson BW, Barrett JS, Cao K, Cory L, Moore JS, Bantly AD, et al: Potent obatoclax cytotoxicity and activation of triple death mode killing across infant acute lymphoblastic leukemia. Blood 121: 2689-2703, 2013.

4. Wang F, Liu Z, Zeng J, Zhu H, Li J, Cheng X, Jiang T, Zhang L, Zhang C, Chen T, et al: Metformin synergistically sensitizes FLT3-ITD-positive acute myeloid leukemia to sorafenib by promoting mTOR-mediated apoptosis and autophagy. Leuk Res 39: 1421-1427, 2015.

5. Kim Y, Eom JI, Jeung HK, Jang JE, Kim JS, Cheong JW, Kim YS and Min YH: Induction of cytosine arabinoside-resistant human myeloid leukemia cell death through autophagy regulation by hydroxychloroquine. Biomed Pharmacother 73: 87-96, 2015.

6. Zauli G, Celeghini C, Melloni E, Voltan R, Ongari M, Tiribelli M, di Iasio MG, Lanza F and Secchiero P: The sorafenib plus nutlin-3 combination promotes synergistic cytotoxicity in acute myeloid leukemic cells irrespectively of FLT3 and p53 status. Haematologica 97: 1722-1730, 2012.

7. Martelli AM, Lonetti A, Amadori S, McCubrey JA and Chiarini F: Enhancing the effectiveness of nucleoside analogs with mTORC1 blockers to treat acute myeloid leukemia patients. Cell Cycle 12: 1815-1816, 2013.

8. Liu C, Xu P, Chen D, Fan X, Xu Y, Li M, Yang X and Wang C: Roles of autophagy-related genes Beclin-1 and LC3 in the development and progression of prostate cancer and benign prostatic hyperplasia. Biomed Rep 1: 855-860, 2013.

9. Liu L, He J, Wei X, Wan G, Lao Y, Xu W, Li Z, Hu H, Hu Z, Luo X, et al: MicroRNA-20a-mediated loss of autophagy contributes to breast tumorigenesis by promoting genomic damage and instability. Oncogene: Jun 19, 2017 (Epub ahead of print).

10. Qiu S, Sun L, Jin Y, An Q, Weng C and Zheng J: Silencing of BAG3 promotes the sensitivity of ovarian cancer cells to cisplatin via inhibition of autophagy. Oncol Rep 38: 309-316, 2017.

11. Brigger D, Proikas-Cezanne T and Tschan MP: WIPI-dependent autophagy during neutrophil differentiation of NB4 acute promyelocytic leukemia cells. Cell Death Dis 5: e1315, 2014.

12. Xie N, Zhong L, Liu L, Fang Y, Qi X, Cao J, Yang B, He Q and Ying M: Autophagy contributes to dasatinib-induced myeloid differentiation of human acute myeloid leukemia cells. Biochem Pharmacol 89: 74-85, 2014

13. Zhang SP, Niu YN, Yuan N, Zhang AH, Chao D, Xu QP, Wang LJ, Zhang XG, Zhao WL, Zhao Y and Wang JR: Role of autophagy in acute myeloid leukemia therapy. Chin J Cancer 32: 130-135, 2013

14. Jin HO, Park JA, Kim HA, Chang YH, Hong YJ, Park IC and Lee JK: Piperlongumine downregulates the expression of HER family in breast cancer cells. Biochem Biophys Res Commun 486: 1083-1089, 2017

15. Bullova P, Cougnoux A, Abunimer L, Kopacek J, Pastorekova S and Pacak K: Hypoxia potentiates the cytotoxic effect of piperlongumine in pheochromocytoma models. Oncotarget 7: 40531-40545, 2016

16. Wang F, Mao Y, You Q, Hua D and Cai D: Piperlongumine induces apoptosis and autophagy in human lung cancer cells through inhibition of PI3K/Akt/mTOR pathway. Int J Immunopathol Pharmacol 28: 362-373, 2015.

17. Malkan UY, Gunes G, Isik A, Eliacik E, Etgul S, Aslan T, Balaban MS, Haznedaroglu IC, Demiroglu H, Goker H, et al: Rebound thrombocytosis following induction chemotherapy is an independent predictor of a good prognosis in acute myeloid leukemia patients attaining first complete remission. Acta Haematol 134: 32-37, 2015

18. O'Hear C, Inaba H, Pounds S, Shi L, Dahl G, Bowman WP, Taub JW, Pui CH, Ribeiro RC, Coustan-Smith E, et al: Gemtuzumab ozogamicin can reduce minimal residual disease in patients with childhood acute myeloid leukemia. Cancer 119: 4036-4043, 2013.

19. Dhillon H, Chikara S and Reindl KM: Piperlongumine induces pancreatic cancer cell death by enhancing reactive oxygen species and DNA damage. Toxicol Rep 1: 309-318, 2014

20. Yu J, Lan L, Lewin SJ, Rogers SA, Roy A, Wu X, Gao P, Karanicolas J, Aubé J, Sun B and Xu L: Identification of novel small molecule Beclin 1 mimetics activating autophagy. Oncotarget: May 18, 2017 (Epub ahead of print).
21. Tanios R, Bekdash A, Kassab E, Stone E, Georgiou G, Frankel AE and Abi-Habib RJ: Human recombinant arginase I(Co)-PEG5000 [HuArgI(Co)-PEG5000]-induced arginine depletion is selectively cytotoxic to human acute myeloid leukemia cells. Leuk Res 37: 1565-1571, 2013.

22. Liu LL, Long ZJ, Wang LX, Zheng FM, Fang ZG, Yan M, $\mathrm{Xu}$ DF, Chen JJ, Wang SW, Lin DJ and Liu Q: Inhibition of mTOR pathway sensitizes acute myeloid leukemia cells to aurora inhibitors by suppression of glycolytic metabolism. Mol Cancer Res 11: 1326-1336, 2013.

23. Makhov P, Golovine K, Teper E, Kutikov A, Mehrazin R, Corcoran A, Tulin A, Uzzo RG and Kolenko VM: Piperlongumine promotes autophagy via inhibition of Akt/mTOR signalling and mediates cancer cell death. Br J Cancer 110: 899-907, 2014.

24. Wang Y, Wang JW, Xiao X, Shan Y, Xue B, Jiang G, He Q, Chen J, $\mathrm{Xu} \mathrm{HG}$, Zhao RX, et al: Piperlongumine induces autophagy by targeting p38 signaling. Cell Death Dis 4: e824, 2013.

25. Wang KF, Yang H, Jiang WQ, Li S and Cai YC: Puquitinib mesylate (XC-302) induces autophagy via inhibiting the $\mathrm{PI} 3 \mathrm{~K} / \mathrm{AKT} / \mathrm{mTOR}$ signaling pathway in nasopharyngeal cancer cells. Int J Mol Med 36: 1556-1562, 2015.

26. Huang WR, Chiu HC, Liao TL, Chuang KP, Shih WL and Liu HJ: Avian reovirus protein p17 functions as a nucleoporin Tpr suppressor leading to activation of p53,p21 and PTEN and inactivation of PI3K/AKT/mTOR and ERK signaling pathways. PLoS One 10: e0133699, 2015.

27. Zhou ZW, Li XX, He ZX, Pan ST, Yang Y, Zhang X, Chow K, Yang T, Qiu JX, Zhou Q, et al: Induction of apoptosis and autophagy via sirtuin 1- and PI3 K/Akt/mTOR-mediated pathways by plumbagin in human prostate cancer cells. Drug Des Devel Ther 9: 1511-1554, 2015.

28. Tsai JP, Lee CH, Ying TH, Lin CL, Lin CL, Hsueh JT and Hsieh YH: Licochalcone A induces autophagy through $\mathrm{PI} 3 \mathrm{~K} / \mathrm{Akt} / \mathrm{mTOR}$ inactivation and autophagy suppression enhances licochalcone A-induced apoptosis of human cervical cancer cells. Oncotarget 6: 28851-28866, 2015.

29. Sun $H$, Wang $Z$ and Yakisich JS: Natural products targeting autophagy via the PI3K/Akt/mTOR pathway as anticancer agents. Anticancer Agents Med Chem 13: 1048-1056, 2013.

30. Li JP, Yang YX, Liu QL, Pan ST, He ZX, Zhang X, Yang T, Chen XW, Wang D, Qiu JX and Zhou SF: The investigational Aurora kinase A inhibitor alisertib (MLN8237) induces cell cycle G2/M arrest, apoptosis, and autophagy via p38 MAPK and Akt/mTOR signaling pathways in human breast cancer cells. Drug Des Devel Ther 9: 1627-1652, 2015.

31. Henson SM, Lanna A, Riddell NE, Franzese O, Macaulay R, Griffiths SJ, Puleston DJ, Watson AS, Simon AK, Tooze SA and Akbar AN: p38 signaling inhibits mTORC1-independent autophagy in senescent human $\mathrm{CD} 8^{+} \mathrm{T}$ cells. J Clin Invest 124 : 4004-4016, 2014.

32. Liu J, Chang F, Li F, Fu H, Wang J, Zhang S, Zhao J and Yin D: Palmitate promotes autophagy and apoptosis through ROS-dependent JNK and p38 MAPK. Biochem Biophys Res Commun 463: 262-267, 2015.

33. Qin Y, Zhou ZW, Pan ST, He ZX, Zhang X, Qiu JX, Duan W, Yang T and Zhou SF: Graphene quantum dots induce apoptosis, autophagy, and inflammatory response via p38 mitogen-activated protein kinase and nuclear factor- $\kappa \mathrm{B}$ mediated signaling pathways in activated THP-1 macrophages. Toxicology 327: 62-76, 2015.

34. Xiong XX, Liu JM, Qiu XY, Pan F, Yu SB and Chen XQ: Piperlongumine induces apoptotic and autophagic death of the primary myeloid leukemia cells from patients via activation of ROS-p38/JNK pathways. Acta Pharmacol Sin 36: 362-374, 2015.

This work is licensed under a Creative Commons Attribution-NonCommercial-NoDerivatives 4.0 International (CC BY-NC-ND 4.0) License. 